\title{
Validasi Aplikasi Komputer untuk Peningkatan Fokus Atensi pada Anak dengan Gangguan Pemusatan Perhatian (GPP)
}

\author{
Asyiah Ummul Muttaqinah, Laila Qodariah, Fredrick Dermawan Purba \\ Program Studi Psikologi, Fakultas Psikologi, Universitas Padjadjaran, Bandung
}

\begin{abstract}
Abstrak. Penelitian ini merupakan kajian mengenai adaptasi program pelatihan peningkatan fokus atensi kedalam bentuk program komputer. Penelitian ini bertujuan untuk mengembangkan alat penunjang pelatihan peningkatan fokus atensi, dengan cara mengubahnya kedalam bentuk program komputer (piranti lunak). Disain penelitian yang digunakan yaitu metode campuran (mixed method) dengan menggunakan strategi metode campuran konkuren atau satu waktu (concurrent mixed methods), yaitu menggunakan disain penelitian kuantitatif dan kualitatif dalam waktu yang bersamaan. Dalam prosesnya, dilakukan penilaian oleh ahli Game Developer berjumlah satu orang dan ahli psikolog bidang klinis anak dan remaja berjumlah tiga orang. Berdasarkan hasil penilaian dari ahli Game Developer terdapat saran perubahan pada intensitas warna stimulus dan latar belakang layar. Sedangkan berdasarkan penilaian dari ahli psikolog dengan mengunakan teknik Content Validity index (CVI), didapat bahwa piranti lunak "Pelatihan Fokus Atensi" memiliki nilai S-CVI/Average (S-CVI/AVE) = .91 (> .80) yang artinya sudah sesuai dengan teori yang ada. Tahap selanjutnya yaitu user experience oleh psikolog bidang klinis anak berjumlah tiga orang dengan membandingkan penggunaan pada piranti lunak dan alat manual. Hasilnya piranti lunak dinilai lebih praktis dan cenderung minim bias negatif.
\end{abstract}

Kata Kunci: fokus atensi, gangguan pemusatan perhatian, pelatihan, program komputer

\section{Validation of Computerized Application to Improve Focus Attention on Children with Attention Deficit Disorder (ADD)}

Abstract. This research is a study on the adaptation of a training program aimed to increase focused attention into a computer. It aims to develop a tool for such training by applying some adaptations into a computer program (software). This study uses concurrent mixed methods (using quantitative and qualitative research methods at the same time). In the first process, the software was assessed by a Game Developer expert and three child and adolescence clinical psychologists. The expert of Game Developer suggests a change of the intensity of the color of the stimulus and the screen background. Using the Content Validity index (CVI) technique, the psychologists found that the "Attention Focus Training" software has a value of S-CVI/Average $(\mathrm{S}-\mathrm{CVI} / \mathrm{AVE})=.91(>.80)$, indicating its conformity to the existing theories. The next stage is user experience by three child and adolescence clinical psychologists, conducted by comparing the use of the software and manual tools. It shows that the software is more practical and tends to have less negative bias.

Keywords: Attention Deficit Disorder, focused attention, software, training

Korespondensi: Asyiah Ummul Muttaqinah. Email: asyiahummulm@gmail.com 
Pada anak, diperlukan kemampuan untuk melakukan atensi/perhatian pada satu tugas khusus, dan kemampuan dasar yang harus dimiliki anak adalah fokus atensi (Flick, 1998). Pada umumnya anak usia 9-10 tahun diharapkan sedang menjalani pendidikan sekolah dasar. Dalam proses pendidikan tersebut anak dihadapkan dengan berbagai kegiatan yang bertujuan untuk meningkatkan kemampuan yang dimiliki dan mengerjakan tugas yang diberikan.

Ketika anak kesulitan untuk memusatkan perhatian pada stimulus tertentu disebut dengan gangguan pemusatan perhatian (GPP). Anak mengalami kesulitan dalam memusatkan perhatian dalam waktu tertentu, lalai, dan sembrono; hiperaktif yaitu ketika terus bergerak; dan impulsif yaitu ketika anak bertindak tanpa berpikir (Mash \& Wolfe, 2014). Menurut Curatolo, D’Agati dan Moavero, ketika dilakukan pemindaian otak pada anak yang mengalami GPP ditemukan perbedaan volume pada area prefontal cortex, basal ganglia, dan cerebellum jika dibandingkan dengan anak seusianya (Noer, 2018). Sedangkan prefrontal cortex sendiri merupakan bagian otak yang bertugas untuk membuat perencanaan (Noer, 2018). Selain itu, lobus frontal dan prefrontal cortex juga bertugas untuk meregulasi atensi, mengendalikan reaksi emosi dan motorik, serta berfikir kritis (Kolb et al., 2016; Mash \& Wolfe, 2014; Siregar, 2018).

Permasalahan mendasar yang sering dialami oleh anak dengan GPP adalah mempertahankan kemampuan atensi yang dimiliki (Flick, 1998). Anak dengan GPP memiliki kecenderungan untuk memperhatikan berbagai hal (Flick, 1998). Sejalan dengan itu, Barkley (Tucha et al, 2011) berpendapat bahwa anak yang mengalami GPP memiliki kecenderungan mudah terdistraksi, memiliki masalah dalam perencanaan, mengorganisasi, dan menyelesaikan tugas yang sedang dikerjakan. Pada anak usia 9-10 tahun yang mengalami GPP, pola permasalahan yang ditimbulkan di rumah dan di sekolah semakin beragam jika dibandingkan dengan anak yang memiliki usia lebih muda. Anak cenderung kesulitan untuk bisa duduk dengan tenang, fokus pada tugas atau materi yang diberikan, dan terus bersama dengan siswa lain di dalam kelas, kesulitan dalam mengikuti aturan yang ada dan juga menyelesaikan tugas yang diberikan (Flick, 1998).

Sebelumnya, terdapat permainan untuk melatih atensi yang disusun oleh Flick (1998) yang dikenal dengan nama Attend- $\mathrm{O}^{\mathrm{TM}}$. Permainan ini bertujuan untuk melatih keseluruhan aspek atensi yang disusun secara bertahap dan disesuaikan dengan proses atensi yang terjadi dalam kehidupan sehari-hari. Permainan ini yang kemudian menjadi acuan sebuah pelatihan fokus atensi yang disusun oleh Fransisca (2014). Pelatihan fokus atensi yang disusun oleh Fransisca (2014) merupakan salah satu penelitian yang bertujuan untuk meningkatkan kemampuan fokus atensi pada anak yang mengalami GPP yaitu penelitian 
yang dilakukan oleh Fransisca (2014). Penelitian ini dilakukan kepada tiga anak usia 9-10 tahun yang mengalami GPP. Media yang digunakan kartu berwarna merah yang diperlihatkan dalam jangka waktu tertentu dan juga kata "Merah" yang diperdengarkan dalam waktu tertentu. Tugas yang diberikan yaitu anak diminta memberikan respon ketika melihat kartu merah dengan menekan tombol respon. Anak akan mendapat skor 1 apabila berhasil menekan tombol respon ketika diperlihatkan kartu merah. Hasil uji coba menggunakan program statistik diketahui bahwa pelatihan dengan pemberian warna merah secara visual dan auditori dapat meningkatkan fokus atensi pada anak usia 9-10 tahun yang mengalami GPP.

Berdasarkan hasil tinjauan peneliti terhadap alat penunjang pelatihan fokus atensi yang disusun oleh Fransisca (2014) yaitu bahwa: (1) Alat tersebut telah sesuai dengan prinsip fokus atensi yang disusun oleh Flick (1998), dan (2) Setelah dianalisis dengan menggunakan uji wilcoxon signed rank dengan tahap kepercayaan 95, hasil yang didapat yaitu $t$ hit $=0$ dan $t$ tabel $=.1250(t$ hit $<t$ tab $)$ alat ini telah terbukti dapat meningkatkan fokus atensi pada anak usia 9-10 tahun yang mengalami GPP sebesar 20.1\% - 27.6\%. Namun terdapat beberapa hal yang menjadi catatan oleh peneliti, yaitu: (1) pada tahap persiapan pelatihan, perlu adanya latihan yang dilakukan oleh fasilitator untuk menampilkan kartu merah agar sesuai dengan waktu yang telah ditentukan. Hal ini tentunya akan membutuhkan cukup waktu agar dapat mahir menampilkan kartu secara tepat (2) alat yang cukup banyak dan besar, membuat alat ini tidak mudah untuk dibawa-bawa, (3) proses pencatatan skor yang dilakukan oleh observer dengan melakukan observasi ketika bermain. Proses pencatatan yang dilakukan oleh manusia, memungkinkan untuk terjadinya human error. Oleh karena itu diperlukan adaptasi lebih lanjut untuk dapat mengembangkan alat penunjang pelatihan yang telah disusun ini, agar dapat lebih memudahkan dalam proses persiapan dan penggunaannya, serta dapat meminimalisir kemungkinan terjadinya human error.

Berdasarkan hasil penelitian yang dilakukan Ford, et al. (Flick, 1998) pelatihan dengan menggunakan media komputer dapat meningkatkan motivasi anak untuk tetap mengerjakan tugas dalam waktu yang lama selama penelitian berlangsung. Bentuk komputer yang memiliki daya tarik yang kuat dapat menarik minat anak pada tugas yang sedang dikerjakan (Flick, 1998). Selain itu, penelitian yang telah dilakukan oleh Dr. Judy Wood (Flick, 1998) dapat membantu orangtua dan guru agar dapat melanjutkan penelitian tersebut pada dua situasi (sekolah dan rumah). Selanjutnya, penelitian dengan metode eksperimen lainnya yaitu oleh Lim et al. (2019) yang bertujuan untuk membuktikan apakah Brain-Computer-Interface (BCI) dapat memperbaiki gejala kurang perhatian pada anak-anak dengan GPPH. Partisipan pada penelitian ini adalah anak-anak berusia 6-12 
tahun yang menghadiri klinik psikiatri rawat jalan dan didiagnosis dengan Gangguan Pemusatan Perhatian dan Hiperaktivitas (GPPH). Hasil dari penelitian ini menunjukkan bahwa program pelatihan atensi berbasis BCI dapat meningkatkan perbaikan masalah pada GPPH. Penguatan atas temuan tersebut juga ditemukan pada riset oleh Lim et al. (2019). Peneliti tersebut melakukan tinjauan literatur yang melakukan penelitian tentang intervensi berbasis teknologi pada anak dengan GPPH dimulai dari Febuari 2019 hingga Febuari 2020. Partisipan penelitian ialah anak-anak dengan GPPH dengan mayoritas berusia 12 tahun ke bawah. Hasil dari penelitian ini adalah penggunaan teknologi telah membantu intervensi pada individu dengan GPPH menjadi lebih mudah, karena dapat dilakukan di sekolah dan di rumah. Teknologi dalam percobaan awal juga tampak menjanjikan sebagai alternatif intervensi (Al-Shathri et al., 2013; Lavigne et al., 2011; Steiner et al, 2011). Berdasarkan pada temuan tersebut, maka tampak bahwa ada peluang penggunaan teknologi sebagai bagian dari intervensi bagi anak dengan GPPH.

Hasil penelitian Evan dan Miller (1969) menemukan bahwa penelitian dengan menggunakan komputer dapat menurunkan respon bias yang dapat terjadi tes psikologi dan juga kuesioner atau survei. Bias yang sering terjadi yaitu kecerobohan, kurangnya keterbukaan, kesulitan dalam memberikan respon terutama yang berkaitan dengan nilai sosial dikarenakan adanya kekhawatiran terhadap adanya evaluasi negatif. Artinya ketika menggunakan komputer, partisipan akan lebih merasa nyaman dalam memberikan respon, memberikan jawaban secara jujur, dan cenderung merasakan emosi yang netral jika dibandingkan dengan pemberian tes dengan menggunakan pensil dan kertas ataupun yang berhadapan dengan manusia secara langsung. Penelitian yang dilakukan oleh Mautone et al. (2005) pada anak yang dengan ADHD menghasilkan temuan bahwa anak dapat duduk secara mandiri, meningkatkan pencapaian dan perilaku On-Task selama pembelajaran dengan bantuan Computer-Assisted Instruction (CAI) pada pelajaran matematika.

Namun demikian, hasil penelitian sebelumnya juga masih menunjukkan inkonsistensi dari penggunaan intervensi berbasis komputer pada anak dengan GPPH. Hasil dari tinjauan literatur oleh Sonuga-Barke et al. (2014) menunjukkan inkonsistensi hasil dalam hal efektivitas pelatihan kognitif berbasis komputer dengan GPPH tipe tertentu. Selain itu, Rapport et al. (2013) dalam studi metaanalisisnyajuga menunjukkan bahwa hasil dari pelatihan kognitif bagi anak GPPH masih lemah dalam metodologi dan desain penelitian di lapangan. Dengan demikian, kesimpulan yang diambil terkait efektivitas metode intervensi ini masih diragukan. Hal ini mengindikasikan adanya permasalahan penelitian yang mengemuka dalam studi ini. Peneliti menganggap perlu penelitian tentang masalah tersebut. 
Berdasarkan pemaparan di atas, maka tujuan dari penelitian ini adalah untuk mengadaptasi pelatihan fokus atensi yang telah dilakukan oleh Fransisca (2014) ke dalam program komputer (piranti lunak). Adaptasi pelatihan menjadi bentuk program komputer (piranti lunak) menunjukkan adanya keterbaruan yang ditawarkan dalam penelitian ini. Hal ini dilakukan untuk mengembangkan alat penunjang pelatihan fokus atensi agar memungkinkan untuk dengan mudah digunakan oleh psikolog, lebih terstandarisasi, tidak menimbulkan bias pada anak, dan meningkatkan kinerja anak selama pelatihan. Tahapan yang dilakukan dalam penelitian ini yaitu dengan terlebih dahulu mengadaptasi alat penunjang pelatihan manual yang disusun oleh Fransisca (2014) ke dalam bentuk program komputer (piranti lunak) dan melakukan penilaian terhadap piranti lunak yang telah disusun dengan melakukan perbandingan terhadap alat manual berdasarkan beberapa aspek. Penilaian ini dilakukan oleh orang yang dapat menggunakan piranti lunak ini dalam intervensi Fokus Atensi, atau selanjutnya akan disebut sebagai Psikolog Pengguna.

\section{Metode}

\section{Prosedur penelitian}

Penelitian ini menggunakan disain concurrent mixed methods, yaitu menggunakan disain penelitian kualitatif dan kuantitatif dalam waktu yang bersamaan, kemudian menggabungkan hasilnya untuk mendapatkan informasi secara menyeluruh (Creswell, 2014). Langkah-langkah penyusunan konsep piranti lunak pelatihan fokus atensi menggunakan studi perancangan pelatihan yang disusun oleh Kohls (1995). Adapun tahap penyusunan pelatihan tersebut adalah sebagai berikut: (1) Tahap analisis. Pada tahapan ini dilakukan analisis kebutuhan, analisis kegiatan, tugas yang harus dilakukan, alat yang akan digunakan, standar kinerja, serta lokasi pelaksanaan kegiatan; (2) Tahap perancangan dan penyusunan program. Pada tahapan ini akan disusun gambaran umum pelatihan, tujuan pelatihan, urutan kegiatan dan alokasi waktu, alat penunjang pelatihan (aktivitas pembelajaran, modul, media dan teknik penyampaian, fasilitator, dan lain sebagainya), evaluasi disain, sarana dan prasarana penunjang, penyusunan materi kegiatan (misalnya modul, dan formulir evaluasi), pelatihan untuk fasilitator, dan validasi dan revisi terhadap masing-masing alat penunjang pelatihan; (3) Tahap pelaksanaan pelatihan. Pada tahapan ini yang akan dilakukan yaitu penyusunan atau persiapan alat penunjang pelatihan, kemudian menjalankan program pelatihan yang telah dirancang; dan (4) Tahap evaluasi. Tahapan ini dilakukan untuk menilai jalannya pelatihan dan juga perubahan yang terjadi pada peserta. Hal yang dapat dilakukan adalah self evaluation, internal evaluation, dan eksternal evaluation untuk kemudian dilakukan revisi terhadap pelatihan yang telah digunakan. Pada penelitian ini, akan menggunakan tahap 1 hingga 2, yaitu analisis kebutuhan hingga evaluasi rancangan program pelatihan. 
Terdapat lima langkah dalam penelitian ini, yaitu: (1) Studi literatur untuk mendapatkan data secara aktual dan sistematis mengenai fenomena yang sedang diteliti melalui hasil kajian yang pernah diteliti sebelumnya; (2) Penyusunan piranti lunak oleh programmer dengan menggunakan teknik pengkodean; (3) Penilaian piranti lunak oleh seorang ekspert game developer dengan mempertimbangkan kriteria kenyamanan anak pada umunya ketika menggunakan alat ini; (4) Penilaian oleh ekspert psikolog bidang klinis anak dan remaja dengan mempertimbangkan mengukur kenyamanan anak dengan GPP ketika menggunakan alat ini dan kesesuaiannya dengan penelitian sebelumnya dan (5) penilaian dari psikolog bidang klinis anak sebagai pengguna program komputer ini nantinya.

\section{Metode pengumpulan data}

Pengumpulan data penilaian dilakukan dengan lembar penilaian yang berbeda-beda untuk setiap tahap. Untuk Ekspert Game Developer digunakan Lembar Penilaian Alat Pelatihan Fokus Atensi untuk Ekspert Game Developer (LP.APFA_GD) yang disusun oleh peneliti berjumlah 10 aitem yang terdiri dari aitem yang menilai Konten, kegunaan, dan efisiensi. Contoh itemnya adalah: "Penempatan objek, misalkan stimulus (Kotak Merah), icon mulai, dan kotak pengisian identitas pada bagian tengah layar". Untuk ekspert psikolog bidang klinis anak dan remaja adalah dengan menggunakan Lembar Penilaian Alat Pelatihan Fokus Atensi untuk Psikolog Klinis Anak dan Remaja (LP.APFA_PKLA) yang disusun oleh peneliti yang terdiri dari 15 aitem. Contoh itemnya adalah: "Apakah tugas yang dikerjakan anak sudah sesuai dengan teori fokus atensi?". Untuk pengguna, digunakan Lembar Penilaian Alat Pelatihan Fokus Atensi Oleh Pengguna (LP.APFA_U) yang disusun oleh peneliti dan terdiri dari 11 aitem. Contoh itemnya adalah: "Alat yang digunakan dapat membuat anak lebih termotivasi untuk mengikuti pelatihan hingga selesai“.

\section{Responden penelitian}

Berikut adalah kriteria responden untuk setiap tahap. Untuk Ekspert Game Developer: (a) minimal lulusan S1 Teknik Informatika; (b) memahami konsep dasar pembuatan game; dan (c) pernah merancang dan membuat game sendiri. Penelitian ini menggunakan satu orang ekspert game developer.

Untuk ekspert psikolog, kriterianya adalah: (a) lulusan magister psikologi profesi; (b) memahami topik mengenai anak dengan GPP dan pernah berinteraksi langsung dengan anak yang mengalami GPP; dan (c) memiliki pengalaman menangani anak yang mengalami GPP. Penelitian ini menggunakan tiga orang ekspert psikolog klinis anak dan remaja.

Untuk psikolog sebagai pengguna, kriterianya adalah: (a) lulusan Magister Psikologi Profesi yang telah berpraktik atau pernah menjadi asisten psikolog; (b) memahami topik GPP; dan (c) pernah menangani anak yang mengalami GPP (Baik ditangani secara mandiri atau melakukan referral). Penelitian ini menggunakan tiga orang psikolog klinis anak dan remaja sebagai pengguna. 


\section{Analisa data}

Penilaian secara kuantitatif dilakukan dengan mengumpulkan skor yang diberikan ekspert psikolog maupun ekspert pengguna. Skor ini kemudian dianalisis dengan menggunakan teknik Content Validity Index (CVI) untuk mengetahui seberapa besar alat atau pelatihan yang disusun tersebut sesuai dengan teori yang digunakan acuan. Sebuah alat dikatakan sudah sesuai apabila memiliki nilai Average Value Explained S-CVI/AVE > .80 yang artinya sebanyak $80 \%$ evaluator atau ekspert yang memberikan penilaian setuju bahwa intervensi ini valid atau sesuai dengan teori acuan (Polit et al., 2007).

\section{Hasil}

Tujuan dari penelitian ini adalah untuk mengadaptasi pelatihan fokus atensi yang telah dilakukan oleh Fransisca (2014) ke dalam program komputer (piranti lunak). Adapun hasil penelitian sebagaimana berikut ini.

\section{Penyusunan materi latihan}

Materi latihan disusun berdasarkan adaptasi alat pelatihan fokus atensi Fransisca (2014) kedalam bentuk piranti lunak. Pelatihan dilakukan dengan menampilkan kartu berwarna merah secara berulang. Sebelum dan sesudah pelatihan berlangsung, akan dilakukan tes untuk mengetahui perkembangan kemampuan fokus atensi anak setelah diberikan pelatihan. Pelatihan dilakukan selama lima pertemuan dengan alokasi waktu maksimal
60 menit. Permainan akan berlangsung selama empat menit dan terbagi menjadi empat interval (satu interval selama 1 menit/ 60 detik). Pelatihan ini terdiri dari level 1 dan level 2. Pada level 1 kartu akan diperlihatkan selama 2 detik (30 kartu), sedangkan pada level 2 kartu akan diperlihatkan selama 1 detik (60 kartu). Level 1 dilakukan pada pertemuan 1-2, dan level 2 dilakukan pada pertemuan 3-5. Anak diminta untuk menekan tombol respon pada response box (terdiri dari lampu indikator dan tombol respon) setiap kali kartu diperlihatkan. Skor 1 didapat ketika anak berhasil menekan tombol setiap kartu diperlihatkan, sedangkan skor 0 diberikan ketika anak tidak berhasil menekan tombol ketika kartu diperlihatkan. Selain itu akan dilakukan observasi terhadap perilaku yang ditampilkan anak selama pelatihan berlangsung. Data ini akan digunakan sebagai data penunjang atau data tambahan.

Metode yang akan dilakukan untuk meadaptasi materi pelatihan fokus atensi dengan menggunakan "Kartu Berwarna Merah" yaitu studi literasi. Adaptasi yang akan dilakukan yaitu berupa pengadaptasian program pelatihan fokus atensi dengan menggunakan "Kartu Berwarna Merah" kedalam bentuk piranti lunak di komputer. Penyusunan rancangan piranti lunak yaitu dengan menentukan latar belakang layar, warna kartu yang ditampilkan, jenis tugas, jenis rangsang, jeda antar kartu, tingkat kesulitan, tampilan instruksi, bentuk tampilan skor, dan tombol respon dapat dilihat di Tabel 1. 


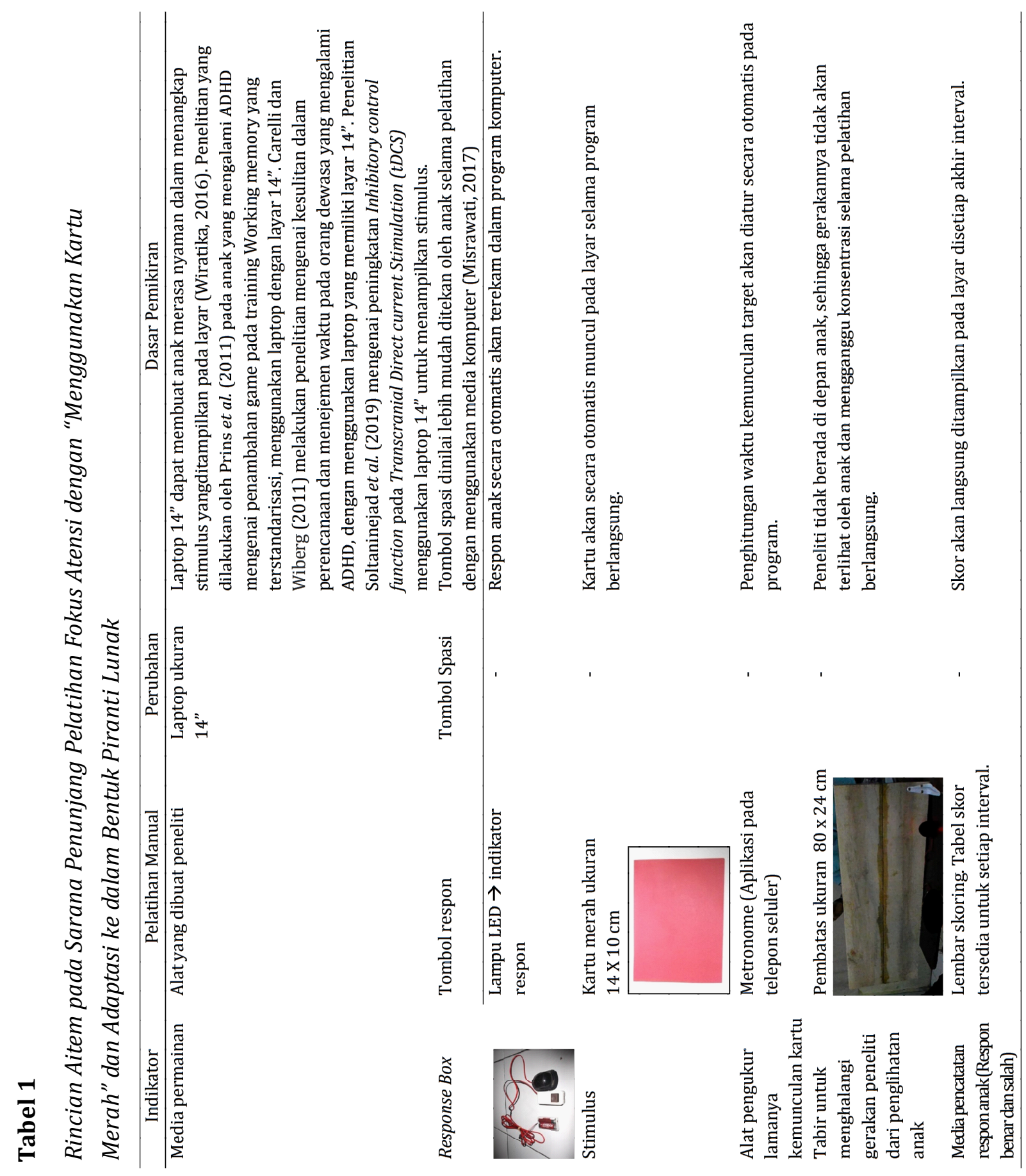




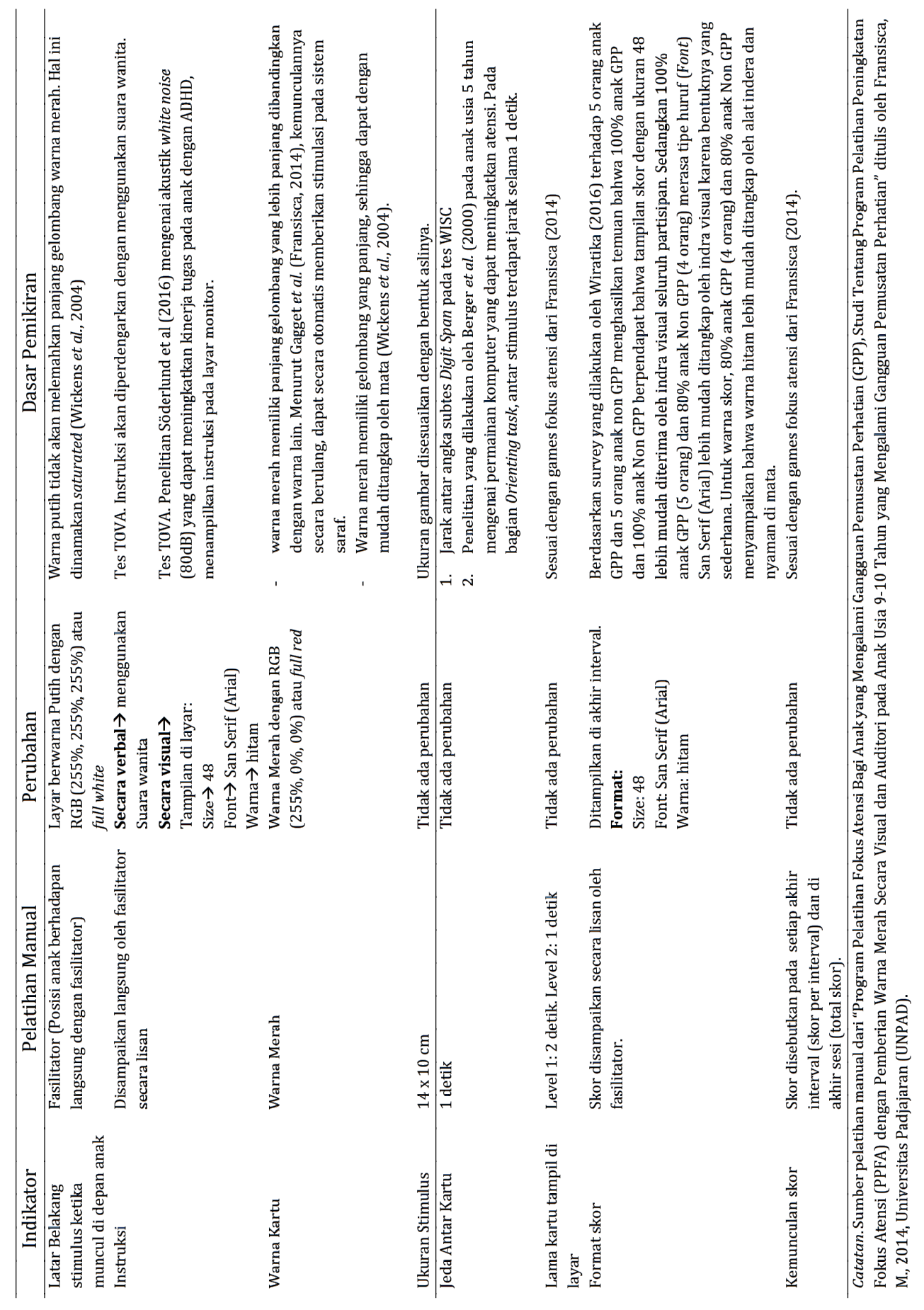




\section{Penilaian piranti lunak pelatihan fokus atensi secara kuantitatif oleh ekspert psikolog}

Rincian skor yang diberikan oleh ketiga ekspert psikolog dapat dilihat pada Tabel 2.

\section{Tabel 2}

Hasil Perhitungan dari Penilaian Ekspert Psikolog

\begin{tabular}{|c|c|c|c|c|c|}
\hline Aspek & Ekspert 1 & Ekspert 2 & Ekspert 3 & $\begin{array}{c}\text { Ekspert } \\
\text { in Agreement }\end{array}$ & $\begin{array}{c}\text { CVI Aitem } \\
\text { (I-CVI) }\end{array}$ \\
\hline Konten1 & $\sqrt{ }$ & $\sqrt{ }$ & $\sqrt{ }$ & 3 & 1.00 \\
\hline Konten 2 & $\sqrt{ }$ & $\sqrt{ }$ & $\sqrt{ }$ & 3 & 1.00 \\
\hline Konten 3 & $\sqrt{ }$ & $\sqrt{ }$ & $\sqrt{ }$ & 3 & 1.00 \\
\hline Konten 4 & $\sqrt{ }$ & $\sqrt{ }$ & $\sqrt{ }$ & 3 & 1.00 \\
\hline Konten 5 & - & $\sqrt{ }$ & $\sqrt{ }$ & 2 & .67 \\
\hline Kegunaan 1 & $\sqrt{ }$ & $\sqrt{ }$ & $\sqrt{ }$ & 3 & 1.00 \\
\hline Kegunaan 2 & $\sqrt{ }$ & - & $\sqrt{ }$ & 2 & .67 \\
\hline Kegunaan 3 & $\sqrt{ }$ & $\sqrt{ }$ & $\sqrt{ }$ & 3 & 1.00 \\
\hline Efisiensi 1 & $\sqrt{ }$ & $\sqrt{ }$ & $\sqrt{ }$ & 3 & 1.00 \\
\hline Efisiensi 2 & $\sqrt{ }$ & - & $\sqrt{ }$ & 2 & .67 \\
\hline $\begin{array}{l}\text { Keterkaitan dengan } \\
\text { teori } 1\end{array}$ & $\sqrt{ }$ & $\sqrt{ }$ & - & 2 & .67 \\
\hline $\begin{array}{l}\text { Keterkaitan dengan } \\
\text { teori } 2\end{array}$ & $\sqrt{ }$ & $\sqrt{ }$ & $\sqrt{ }$ & 3 & 1.00 \\
\hline $\begin{array}{l}\text { Keterkaitan dengan } \\
\text { teori } 3\end{array}$ & $\sqrt{ }$ & $\sqrt{ }$ & $\sqrt{ }$ & 3 & 1.00 \\
\hline $\begin{array}{l}\text { Kesesuaian dengan } \\
\text { penelitian } \\
\text { sebelumnya } 1\end{array}$ & $\sqrt{ }$ & $\sqrt{ }$ & $\sqrt{ }$ & 3 & 1.00 \\
\hline \multirow[t]{2}{*}{$\begin{array}{l}\text { Kesesuaian dengan } \\
\text { penelitian } \\
\text { sebelumnya } 2\end{array}$} & $\sqrt{ }$ & $\sqrt{ }$ & $\sqrt{ }$ & 3 & 1.00 \\
\hline & & & & $\begin{array}{l}M \mathrm{I}-\mathrm{CVI} \\
\text { (S-CVI/AVE) }\end{array}$ & .91 \\
\hline
\end{tabular}

Catatan. Proporsi Relevan .93, .87, .93.

I-CVI = item-level content validity index; scale-level content validity index, averaging method (I$\mathrm{CVI} / \mathrm{AVE})=.91$; proporsi rata-rata item yang dinilai relevan untuk ketiga ahli $=.91$.

Berdasarkan hasil perhitungan, diketahui bahwa alat hasil adaptasi (piranti lunak) memiliki skor S-CVI/AVE $=.91(n>.80)$. Berdasarkan hasil perhitungan dengan S-CVI/ AVE, diketahui bahwa alatyang disusun ini telah sesuai dengan teori acuan. Polit, et al. (2007) mengemukakan bahwa S-CVI/UA sulit untuk diraih. Selain itu, pendekatan ini mengabaikan resiko adanya bias jawaban dari ekspert yang dikarenakan kesalahpahaman mengenai isi lembar penilaian. Sedangkan, pendekatan dengan menggunakan S-CVI/ AVE cenderung menarik untuk digunakan. Hal ini dikarenakan metode ini dapat meminimalisasi timbulnya masalah, namun tetap dapat menjelaskan pengaruh aitem yang ada dengan melalui nilai 
rata-rata. Oleh karena itu, peneliti menyimpulkan bahwa alat ini memiliki skor SCVI/AVE sebesar 91 yang artinya alat yang disusun ini telah sesuai dengan teori yang diacu.
Setelah mendapatkan penilaian dan masukan dari ekspert game developer dan ekspert psikolog klinis anak dan remaja, maka dilakukan revisi (Tabel 3).

\section{Tabel 3}

Kesimpulan dan Saran Ekspert Serta Revisi yang Dilakukan

\begin{tabular}{|c|c|c|c|}
\hline Konten & Saran & Pemberi Saran & Keterangan \\
\hline $\begin{array}{l}\text { Tata letak icon } \\
\text { permainan }\end{array}$ & $\begin{array}{lrr}\text { Lebih diperbesar } & \text { dan } \\
\text { diberi warna } & \text { yang } \\
\text { mencolok } & \end{array}$ & Ekspert Psikolog 2 & Diubah \\
\hline $\begin{array}{l}\text { Warna latar } \\
\text { belakang putih }\end{array}$ & $\begin{array}{l}\text { Diganti dengan warna } \\
\text { yang agak redup, RGB } \\
(225 \%, 225 \%, 225 \%)\end{array}$ & Ekspert Game Developer & $\begin{array}{l}\text { Diubah } \\
\text { (Berdasarkan } \\
\text { penilaian dari }\end{array}$ \\
\hline $\begin{array}{l}\text { Warna merah } \\
\text { stimulus }\end{array}$ & $\begin{array}{l}\text { Tone warna agak } \\
\text { diturunkan, RGB }(225 \% \text {, } \\
0 \%, 0 \%)\end{array}$ & Ekspert Game Developer & $\begin{array}{l}\text { ekspert } \\
\text { psikolog) }\end{array}$ \\
\hline $\begin{array}{l}\text { Penyampaian } \\
\text { instruksi } \\
\text { secara verbal } \\
\text { dan visual }\end{array}$ & $\begin{array}{l}\text { Gunakan kalimat pendek } \\
\text { dan sesuaikan dengan } \\
\text { suara yang timbul }\end{array}$ & $\begin{array}{l}\text { Ekspert Psikolog } 1 \text { dan Ekspert } \\
\text { Game Developer }\end{array}$ & Diubah \\
\hline
\end{tabular}

\section{Penilaian oleh psikolog sebagai pengguna}

Tahap User Experience (UX) merupakan tahapan akhir dalam penelitian ini. Psikolog pengguna yang terlibat dalam penelitian ini merupakan tiga orang psikolog yang sudah pernah menangani anak dengan GPP. Pada tahapan ini, pengguna terlebih dahulu diminta untuk memberikan penilaiannya setelah mencoba menonton video contoh pemakaian alat pelatihan manual dan coba menggunakan piranti lunak pelatihan fokus atensi. Kemudian mengisi LP.APFA_U. Hasilnya dapat dilihat di Tabel 4.

\section{Tabel 4}

Rekapitulasi Penilaian Pengguna

\begin{tabular}{lcccccc}
\hline \multirow{2}{*}{ Aitem } & \multicolumn{5}{c}{ Manual } & \multicolumn{3}{c}{ Program Komputer } \\
\cline { 2 - 7 } & Pengguna 1 & Pengguna 2 & Pengguna 3 & Pengguna 1 & Pengguna 2 & Pengguna 3 \\
\hline Aitem 1 & 3 & 3 & 2 & 3 & 4 & 4 \\
Aitem 2 & 3 & 3 & 3 & 3 & 4 & 4 \\
Aitem 3 & 3 & 3 & 2 & 3 & 3 & 5 \\
Aitem 4 & 3 & 2 & 3 & 3 & 2 & 4 \\
Aitem 5 & 3 & 3 & 3 & 3 & 4 & 4 \\
Aitem 6 & 3 & 3 & 2 & 3 & 3 & 4 \\
Aitem 7 & 3 & 3 & 2 & 3 & 3 & 5 \\
Aitem 8 & 3 & 4 & 3 & 3 & 5 & 5 \\
Aitem 9 & 3 & 2 & 2 & 3 & 5 & 5 \\
Aitem 10 & 4 & 3 & 2 & 4 & 5 & 4 \\
Aitem 11 & 3 & 1 & 1 & 3 & 5 & 49 \\
$n$ & 34 & 42 & 30 & 42 & 43 & \\
\hline
\end{tabular}

Catatan. $\mathrm{N}$ manual $=89 ; \mathrm{N}$ program komputer $=134$. 
Adapun pemaparan hasil penilaian pengguna adalah sebagai berikut:

\section{Hasil penilaian psikolog satu}

Psikolog 1 merupakan psikolog yang berpraktek di biro psikologi S di Kota Bandung. Sebelumnya sudah pernah menggunakan alat manual. Berdasarkan pengalaman sebelumnya, psikolog satu merasa cukup kesulitan ketika menggunakan alat tersebut. Selain dari persiapan yang membutuhkan waktu yang lebih lama, merasa agak kesulitan ketika memunculkan kartu (terkadang lebih cepat atau lebih lambat ketika ada hal yang mengganggu konsentrasi), dan terkadang tabir penutup bisa jatuh saat pelatihan berlangsung, sehingga harus memulai pelatihan dari awal lagi.

Berdasarkan hasil penilaian, skor total untuk alat manual adalah 34, dan piranti lunak adalah 42. Sehingga total skor penilaian piranti lunak lebih besar jika dibandingkan dengan skor penilaian alat manual. Hal ini dikarenakan pada penilaian piranti lunak lebih banyak skor 4 (Setuju) dan 5 (Sangat Setuju) terhadap pernyataan yang ada, yaitu skor 4 (Setuju) dengan pernyataan "alat dapat membuat anak meningkatkan skor, tidak menimbulkan bias, dan menarik minat anak". Sedangkan skor 5 (Sangat Setuju) dengan pernyataan "alat mudah dipersiapkan, mudah digunakan, dan mudah dibawa-bawa". Sedangkan untuk penilaian alat manual, skor 4 (Setuju) terdapat pada pernyataan "alat mudah digunakan".
Menurut psikolog 1, kedua alat ini sudah sama-sama dapat melatih atensi dan bermanfaat bagi anak, yang membedakan hanya pada faktor kemudahan saja, piranti lunak lebih mudah dipersiapkan dan digunakan. Ketika menggunakan piranti lunak, psikolog 1 merasa adanya afterimage atau gambar yang serupa dengan stimulus, namun memiliki warna lain setelah kemunculan stimulus kartu merah dan membuatnya merasa sedikit pusing. Menurutnya, bisa saja dikarenakan warna stimulus dengan latar belakang yang kontras, atau dikarenakan dalam kondisi berkacamata.

Psikolog satu memilih piranti lunak sebagai alat yang ingin dilakukan dalam intervensi fokus atensi dikarenakan lebih praktis, kemungkinan human error akan lebih sedikit terjadi dan kemunculan kartu lebih teratur, dapat melakukan observasi dan mencatatnya secara langsung selama pelatihan berlangsung karena alat dapat berjalan dengan sendirinya sehingga tidak menghilangkan data yang ada, adanya perhitungan benar dan salah secara akurat.

Psikolog satu menyarankan untuk melakukan penelitian lanjutan dengan merubah warna latar belakang menjadi hitam sesuai dengan latar belakang yang digunakan pada tes TOVA. Selain itu disarankan untuk menutupi seluruh tombol keyboard dengan hanya memberi tanda pada letak tombol spasi saja. Karena dikhawatirkan dapat berpotensi untuk menarik perhatian anak dan memainkannya selama pelatihan berlangsung. 


\section{Hasil penilaian psikolog dua}

Psikolog dua merupakan psikolog yang berpraktek di Biro Psikologi S dan Sekolah A di Kota Bandung. Berdasarkan hasil penilaian pada tabel 4.7 dan 4.8, skor total penilaian untuk alat manual adalah 30 dan piranti lunak adalah 43 . Dengan demikian, piranti lunak memiliki skor total lebih besar jika dibandingkan dengan skor total alat manual. Hal ini dikarenakan Psikolog dua memberikan 3 skor 4 (Setuju), yaitu pada pernyataan "alat dapat membuat anak lebih termotivasi untuk mengikuti proses pelatihan, anak menikmati proses pelatihan, dan membuat anak berusaha meningkatkan skor". Skor 5 (Sangat Setuju) untuk pernyataan "alat dapat menarik minat anak, mudah dipersiapkan, mudah dioperasikan atau digunakan, dan mudah dibawa-bawa". Sedangkan untuk alat manual, skor 4 (Setuju) untuk pernyataan "Alat dapat menarik minat anak", namun skor 2 (Tidak Setuju) untuk pernyataan alat mudah dipersiapkan, dan skor 1 (Sangat Tidak Setuju) pada pernyataan "alat mudah dibawa-bawa". Untuk pernyataan "alat dapat membuat anak duduk diam" psikolog dua memberi skor 2 (Tidak Setuju) untuk kedua alat (Manual dan piranti lunak). Hal ini dikarenakan kemungkinan pada awalnya anak akan tampak antusias, namun setelah beberapa kali sesi pelatihan, psikolog dua tidak akan seantusias ketika awal pelatihan.

Secara umum alat manual dirasa lebih sederhana dalam penggunaannya, namun untuk persiapan alatnya (dari mulai pembuatan alat hingga persiapan saat pelatihan) dirasa akan sedikit rumit, kecuali telah tersedia alat yang baku di pasaran. Sedangkan, piranti lunak lebih mudah digunakan oleh psikolog muda, sedangkan dibutuhkan usaha lebih untuk menyesuaikan dengan alat yang ada bagi psikolog senior. Ketika sudah mahir menggunakan alat ini, keduanya akan dimudahkan dalam proses administrasi hingga skoring. Alat juga dapat digunakan dimana saja karena mudah dibawa-bawa. Psikolog dua memilih piranti lunak sebagai alat yang ingin digunakan. Hal ini dikarenakan piranti lunak dinilai dapat menarik minat anak.

Saran untuk pengembangan piranti lunak, yaitu terkait dengan tampilan program yang dibuat lebih menarik atau diperhalus. Kemudian perlunya dilakukan studi lanjutan untuk membuat alat khusus sebagai tombol respon yang sesuai. Hal ini dikarenakan dengan banyaknya tombol yang ada pada keyboard dapat mengalihkan perhatian anak dan menimbulkan keinginan untuk memencet tombol lain (penelitian dapat merujuk pada alat yang digunakan pada tes TOVA).

\section{Hasil penilaian psikolog tiga}

Psikolog tiga merupakan psikolog yang berpraktek di Klinik N di Kota Bandung. Berdasarkan hasil penilaian yang dilakukan, total skor untuk alat manual adalah 25 dan piranti lunak adalah 49 maka total skor piranti lunak lebih besar dibandingkan alat manual. Hal ini dikarenakan pada penilaian piranti lunak, psikolog memberikan skor 4 
(Setuju) dan 5 (Sangat Setuju) untuk keseluruhan pertanyaan. Skor 4 (Setuju) pada pernyataan "alat dapat memotivasi anak, anak lebih menikmati pelatihan, anak dapat duduk diam, anak berusaha meningkatkan skor, anak fokus pada kegiatan, dan alat mudah dibawa-bawa". Skor 5 (Sangat Setuju) pada pernyataan "alat dapat membuat anak merasa nyaman, alat tidak menimbulkan bias, alat menarik minat anak, alat mudah dipersiapkan, dan alat mudah dioperasikan atau digunakan". Sedangkan untuk alat manual mendapat skor 2 (Tidak Setuju) pada pernyataan "alat dapat memotivasi anak, alat dapat membuat anak merasa nyaman, alat dapat membuat anak fokus, alat dapat menimbulkan bias, dan alat mudah untuk dioperasikan atau digunakan". Skor 1 (Sangat Tidak Setuju) untuk pernyataan "alat mudah untuk dibawa-bawa".

Pada umumnya alat manual dinilai lebih rumit dari sisi persiapan alat dan ketika memunculkan kartu di depan anak. Ada kemungkinan tester bisa menjadi distraksi bagi anak, sehingga tidak fokus dengan kegiatan yang sedang dilakukan, sedangkan piranti lunak dinilai akan lebih netral bagi anak. Psikolog tiga memilih piranti lunak sebagai alat yang ingin digunakan sebagai alat untuk intervensi fokus atensi pada anak. Hal ini dikarenakan piranti lunak dinilai lebih mudah untuk dipersiapkan dan digunakan, kartu akan muncul secara tepat dan statis, dan data yang ada akan tercatat secara otomatis.
Saran yang diberikan untuk pengembangan piranti lunak "Pelatihan Fokus Atensi" adalah perlu ditambahkan video tutorial cara penginstalan alat, sehingga dapat mempermudah pengguna untuk memahami cara menginstal dan menjalankan program. Selain itu, perlu ditambahkan lembar troubleshoot yang berisikan kemungkinan masalah yang akan muncul selama proses instalasi dan juga solusi yang dapat dilakukan. Hal ini bertujuan agar pengguna dapat terbantu ketika mengalami kendala dalam proses instalasi atau penggunaan alat.

\section{Pembahasan}

Berdasarkan hasil penilaian, ketiga psikolog memberikan nilai yang lebih besar untuk piranti lunak "Pelatihan Fokus Atensi", yaitu dengan skor total 134, sedangkan skor total alat manual yaitu 89. Ketiga psikolog pun memilih piranti lunak sebagai alat yang mungkin akan digunakan dalam intervensi fokus atensi pada anak. Hal ini dikarenakan piranti lunak memiliki beberapa kelebihan jika dibandingkan dengan alat manual, yaitu terkait kepraktisannya dalam hal persiapan, dan penggunaan alat, dan mudah untuk dibawabawa sehingga dapat digunakan dimana saja. Berdasarkan penelitian yang dilakukan oleh Mary J. Ford etal (Flick, 1998) pelatihan dengan menggunakan media komputer dapat meningkatkan motivasi anak untuk tetap mengerjakan tugas dalam waktu yang lama selama penelitian berlangsung. Hal serupa 
disampaikan oleh Bolic et al. (2013) bahwa anak GPP yang menggunakan komputer sebagai alat bantu dalam pembelajaran mengalami peningkatan motivasi, dan kecepatan kerja dibandingkan ketika mengerjakan tugas dengan tulisan tangan. Penelitian yang dilakukan oleh Mautone et al (2005) pada anak yang dengan GPP menghasilkan temuan bahwa anak dapat duduk secara mandiri, meningkatkan pencapaian dan perilaku On-Task selama pembelajaran dengan bantuan CAI pada pelajaran matematika. Sejalan dengan itu, Bolic et al. (2013) menyampaikan bahwa anak dengan GPP yang menggunakan bantuan komputer dalam proses pembelajaran, akan mengalami peningkatan waktu keterlibatan dalam proses pembelajaran, perilaku on-task, peningkatan kemampuan atensi, peningkatan dalam pembelajaran matematis, dan juga membaca.

Selanjutnya piranti lunak juga dinilai lebih terstandarisasi, minim bias bagi anak, serta data yang dihasilkan lebih valid karena secara otomatis tercatat pada alat. Hal ini serupa dengan temuan pada penelitian yang dilakukan oleh Evan dan Miller (1969) menemukan temuan bahwa penggunaan komputer dapat menurunkan respon bias yang dapat terjadi tes psikologi dan juga kuesioner atau survey yang dilakukan pada umunya. Bias yang sering muncul yaitu kecerobohan, kurangnya keterbukaan, kesulitan dalam memberikan respon terutama yang berkaitan dengan nilai sosial dikarenakan adanya kekhawatiran terhadap adanya evaluasi negatif. Hal ini tentunya akan mempengaruhi performa anak selama tes berlangsung.

Terdapat beberapa catatan, yaitu terkait dengan munculnya afterimage yang dapat membuat pusing. Dilansir dari Cherry (2020) bahwa Afterimage merupakan kemunculan gambar yang serupa dengan gambar sebelumnya namun memiliki warna yang sama atau berbeda. Hal ini bisa terjadi dikarenakan terpapar secara singkat oleh stimulus yang sangat cerah terutama ketika kondisi sekitarnya jauh lebih gelap jika dibandingkan dengan stimulus yang ada. Selain itu adanya paparan dari stimulus warna secara terus menerus, meskipun kondisi di sekitarnya samasama terang. Afterimage merupakan kondisi yang umum terjadi dan akan hilang dengan sendirinya. Selanjutnya terkait dengan penggunaan piranti lunak yang kemungkinan kurang familiar untuk psikolog senior, sehingga akan membutuhkan waktu untuk mempelajari cara untuk mempersiapkan dan menjalankan piranti lunak ini, namun saat telah terbiasa, akan memudahkan psikolog dalam melakukan intervensi ataupun melakukan evaluasi terhadap hasil pelatihan yang dilakukan.

Dalam pelatihan fokus atensi dengan menggunakan program komputer ini, anak diminta untuk terus menerus menekan spasi ketika kartu merah muncul. Tujuannya adalah agar anak dapat melatih kemampuannya dalam berespon secara tepat terhadap stimulus tertentu. Mekanisme yang terjadi adalah terlebih 
dahulu anak akan menangkap gambaran stimulus kartu merah dengan panca indera, kemudian memproses gambaran tersebut di otak sebagai suatu stimulus yang harus direspon. Bagian lobus frontal dan prefrontal cortex yang kemudian akan merencanakan dan mengatur respon yang harus diberikan dan akan beradaptasi dengan setiap informasi yang diberikan oleh sel syaraf (Siregar, 2018), dan perilaku yang harus dimunculkan yaitu dengan menekan spasi setelah kartu merah muncul. Setelah itu sistem syaraf bertugas untuk menggerakkan tangan dan menekan spasi. Jika bagian otak ini terus menerus menerima rangsangan maka akan membuatnya merangsang pertumbuhan sel otak atau plastisitas sel otak dan juga sistem syaraf (Kolb et al., 2007; Mash \& Wolfe, 2014; Siregar, 2018). Pada akhirnya anak akan terlatih untuk merespon pada stimulus yang diinginkan. Selain itu pemberian pelatihan dengan menggunakan komputer ini membuat anak lebih menarik minat anak dan termotivasi untuk mengikuti pelatihan karena merasa sedang bermain (Berger et al., 2000; Flick, 1998). Kemudian menurut Ford (1998), hal tersebut dapat membuat anak bertahan untuk terus mengikuti pelatihan hingga selesai. Hal ini tentunya akan membuat proses plastisitas di otak akan semakin sering dengan banyaknya rangsangan yang diberikan.

Mekanisme yang terjadi ketika anak bermain komputer dan melihat skor di layar komputer, anak akan merasa hal ini sebagai sebuah reward. Proses yang terjadi adalah Sistem indera akan menangkap informasi yang berkaitan dengan kemunculan reward tersebut. Selanjutnya hal ini akan diproses di Amigdala dan akan diberi label sebagai sesuatu yang menyenangkan, dan membahagiakan oleh Nucleus Accumbens. Perilaku yang menjadi penyebab timbulnya reward dan situasi yang ada saat itu akan diingat oleh ventral tegmental area (VTA) dan akan menghasilkan dopamine yang akan disimpan pada amigdala. Informasi tersebut kemudian digunakan akan kembali ketika menghadapi situasi yang serupa (Stahl, 2008). Semakin sering proses ini terjadi maka akan semakin banyak neuron yang akan mendapat rangsangan dan membuat plasticity di otak (Stahl, 2008). Pengulangan ini akan diserap oleh prefrontal cortex yang kemudian akan membuat anak akan mengambil kesimpulan untuk mengulangi perilaku yang sama agar mendapatkan reward dan menghasilkan perasaan bahagia (Stahl, 2008). Kemudian anak akan secara otomatis termotivasi ketika melakukan pelatihan dengan menggunakan komputer.

Keterbatasan yang ada pada penelitian ini yaitu belum adanya penilaian yang dilakukan oleh anak, sehingga belum tergambar persepsi anak ketika menggunakan kedua alat tesebut. Selain itu penelitian ini terbatas hanya pada pembuatan alat saja, sehingga belum adanya uji efektifitas penggunaan pelatihan pada anak yang mengalami GPP. Maka dari itu, diperlukan studi lebih lanjut untuk mengetahui efektifitas 
penggunaan piranti lunak dalam peningkatan kemampuan fokus atensi anak.

\section{Simpulan}

Penelitian ini bertujuan untuk mengadaptasi pelatihan fokus atensi yang telah dilakukan oleh Fransisca (2014) ke dalam program komputer (piranti lunak). Proses adaptasi alat pelatihan fokus atensi dengan menggunakan kartu merah bertujuan untuk mengubah alat penunjang pelatihan yang dibuat dan dijalankan secara manual menjadi sebuah piranti lunak. Berdasarkan analisis kebutuhan diperoleh simpulan bahwa alat yang disusun sudah sesuai dengan karakteristik tugas pada fokus atensi, dapat digunakan untuk meningkatkan kemampuan fokus atensi. Namun terdapat hal yang perlu dikembangkan, yaitu terkait dengan ukuran alat penunjang pelatihan yang cukup besar sehingga sulit untuk dibawabawa. Kesulitan lain adalah saat penggunaan alat, yaitu papan yang terjatuh dan juga lampu indikator yang tidak menyala saat pelatihan berlangsung sehingga perlu mengulang di lain hari. Fasilitator harus terlebih dahulu melakukan pelatihan agar dapat menampilkan waktu dengan tepat, harus tetap menampilkan wajah tanpa ekspresi agar tidak mendistraksi anak. Fasilitator juga sulit untuk secara langsung menuliskan hasil observasi dikarenakan harus tetap fokus dengan waktu tampilnya kartu. Dengan demikian perlu dilakukan pengembangan alat penunjang pelatihan yang lebih praktis untuk digunakan oleh psikolog.
Proses adaptasi terlebih dahulu dilakukan dengan menganalisis kebutuhan yang hasilnya kemudian digunakan untuk mengembangkan alat penunjang pelatihan peningkatan fokus atensi. Dengan demikian piranti lunak yang disusun memiliki spesifikasi sebagai berikut: warna merah akan ditampilkan dengan menggunakan Laptop 14" sebagai media untuk menampilkan stimulus sekaligus tombol respon (Tombol Spasi); warna latar belakang layar yaitu abu-abu dengan RGB (225\%, 225\%, $225 \%$ ); dan warna kartu yaitu merah dengan RGB (225\%, 0\%, 0\%). Instruksi akan muncul pada layar dalam bentuk tulisan perkalimat (size: 48, font: San Serif/ Arial, Warna: hitam) bersamaan dengan diperdengarkannya suara sesuai dengan kalimat yang muncul. Skor akan muncul pada layar di setiap akhir interval (format sama dengan tampilan instruksi).

Berdasarkan hasil review yang dilakukan oleh psikolog pengguna (tahap user experience), maka diperoleh simpulan bahwa piranti lunak "Pelatihan Fokus Atensi" dinilai lebih praktis dalam hal persiapan, dan penggunaan alat, dan mudah untuk dibawa-bawa sehingga dapat digunakan dimana saja. Piranti lunak juga dinilai lebih terstandarisasi, minim bias bagi anak, serta data yang dihasilkan lebih valid karena secara otomatis tercatat pada alat.

\section{Saran}

Adapun saran untuk penelitian selanjutnya adalah perlunya dilakukan tahap User Experience atau penilaian terhadap piranti 
lunak yang dilakukan oleh anak yang mengalami GPP atau anak pada umumnya, agar diperoleh tanggapan anak ketika menggunakan piranti lunak ini. Untuk mengoptimalkan alat yang ada, terdapat perubahan yang dapat dilakukan dengan melakukan penelitian lainnya untuk menentukan warna latar belakang layar yang dirasa lebih nyaman, yaitu dengan membandingkan penggunaan warna monocromatik seperti hitam, putih, dan abuabu. Setelah melakukan tahap user experience, perlu dilakukan uji coba pada anak dengan GPP usia 9-10 tahun untuk mengetahui apakah terdapat perubahan pada kemampuan fokus atensi. Selanjutnya dilakukan uji efektivitas pada alat.

\section{Referensi}

Al-Shathri, A., Al-Wabil, \& Al-Ohali, Y. (2013). Eye-controlled games for behavioral therapy of attention deficit disorders. $\mathrm{HCI}$ International 2013 - Posters' Extended Abstracts, 574-578. https://doi.org/ 10.1007/978-3-642-39473-7_114

Berger, A., Jones, L., Rothbart, M. K., \& Al, E. (2000). Computerized games to study the development of attention in childhood. Behavior Research Methods, Instruments, \& Computers 32, 297-303. https://doi.org/10.3758/BF03207798

Bolic, V., Lidström, H., Thelin, N., Kjellberg, A., \& Hemmingsson, H. (2013). Computer use in educational activities by students with ADHD. Scandinavian Journal of Occupational Therapy, 20(5), 357-364. h ttp s: / / do i.org / 10.3109 / 11038128.2012.758777

Cherry, K. (2020). Positive and negative afterimages. VerywellMind. https:// www.verywellmind.com/what-is-anafterimage-2795828
Creswell, J. W. (2014). Research design pendekatan kualitatif, kuantitatif, dan mixed. Pustaka Pelajar.

Evan, M., \& Miller, J. R. (1969). Differential effect on response bias of computer VS conventional administration of a social science questionnaire: An eksploratory methodological eksperiment. Journal Behavioral Science, 14, 216-227. https:/ /doi.org/10.1002/bs.3830140306

Flick, G. L. (1998). ADD/ADHD behavioral change resource kit. The Center For Applied Research In Education.

Fransisca, M. (2014). Program pelatihan fokus atensi bagi anak yang mengalami gangguan pemusatan perhatian (GPP), studi tentang program pelatihan peningkatan fokus atensi (PPFA)dengan pemberian warna merah secara visual dan auditori pada anak usia 9-10 tahun yang mengalami gan. UNPAD.

Kohls, R. L. (1995). Step in training development. In L. Kohls, R, Brussow, \& L. Herbert (Eds.), Training Know-How for Cross Cultural and Diversity Trainer (p. 71). Nicholas Brealy Publishing.

Kolb, B., Morshead, C., Gonzalez, C., Kim, M., Gregg, C., Shingo, T., \& Weiss, S. (2007). Growth factor-stimulated generation of new cortical tissue and functional recovery after stroke damage to the motor cortex of rats. Journal of Cerebral Blood Flow and Metabolism, 27(5), 983-997. https:// doi.org/10.1038/sj.jcbfm.9600402

Lavigne, J. V., Dulcan, M. K., LeBailly, S. A., Binns, H. J., Cummins, T. K., \& Jha, P. (2011). Computer-assisted management of Attention -Deficit/ Hyperactivity Disorder. PEDIATRICS, 128(1), 1-9.

Lim, C. G., Poh, X. W. W., Fung, S. S. D., Guan, C., Bautista, D., Cheung, Y. B., Zhang, H., Yeo, S. N., Krishnan, R., \& Lee, T. S. (2019). A randomized controlled trial of a braincomputer interface based attention training program for ADHD. Plos One, 14(5). https://doi.org/10.1371/ journal.pone.0216225 
Mash, E. J., \& Wolfe, D. A. (2014). Abnormal child psychology (6th ed). Cengage Learning.

Mautone, J. A., DuPaul, G. J., \& Jitendra, A. K. (2005). The effects of computer-assisted instruction on the mathematics performance and classroom behavior of children with ADHD. Journal of Attention Disorders, 9(1), 301-312. https:// doi.org/10.1177/1087054705278832

Misrawati, D. (2017). Pelatihan Selective Visual Attention Pada Anak Yang Mengalami Gangguan Pemusatan Perhatian (GPP Studi Mengenai Perancangan Dan Pelaksanaan Pelatihan Visual Attention Bagi Anak Usia 9-10 Tahun Yang Mengalami Gangguan Pemusatan Perhatian. UNPAD.

Noer, A. H. (2018). Pendekatan biopsikososial dalam psikopatologi perkembangan. In J. R. Siregar (Ed.), Teori, Penelitian, dan Praktik Attention-Deficit Hyperactivity Disorder Pada Anak (pp. 17-28). P.T Alumni.

Polit, D. F., Beck, C. T., \& Owen, S. V. (2007). Is the CVI an acceptable indicator of content validity? Appraisal and recommendations. Research in Nursing \& Health, 30(4), 459-467. https:// doi.org/10.1002/nur.20199

Prins, P. J., Dovis, S., Ponsioen, A., ten Brink, E., \& van der Oord, S. (2011). Does computerized working memory training with game elements enhance motivation and training efficacy in children with ADHD? Cyberpsychology, Behavior and Social Networking, 14(3), 115-122. h ttp s: / / doi.org/10.1089/ cyber.2009.0206

Rapport, M. D., Orban, S. A., Kofler, M. J., \& Friedman, L. M. (2013). Do programs designed to train working memory, other executive functions, and attention benefit children with ADHD? A metaanalytic review of cognitive, academic, and behavioral outcomes. Clinical Psychology Review, 33(8), 1237-1252. h ttp s: / / doi.org/10.1016/ j.cpr.2013.08.005
Siregar, J. R. (2018). Teori, penelitian, dan praktik Attention-Deficit Hyperactivity Disorder pada anak. P.T Alumni.

Soltaninejad, Z., Nejati, V., \& Ekhtiari, H. (2019). Effect of anodal and cathodal transcranial direct current stimulation on DLPFC on modulation of inhibitory control in ADHD. Journal of Attention Disorders, 23(4), 325-332. https:// doi.org/10.1177/1087054715618792

Sonuga-Barke, E., Brandeis, D., Holtmann, M., \& Cortese, S. (2014). Computer-based cognitive training for ADHD: A review of current evidence. Child and Adolescent Psychiatric Clinics, 23(4), 807-824. h ttp s: / / doi.org / 10.1016 / j.chc.2014.05.009

Stahl, S. M. (2008). Stahl's essential psychopharmacology neuroscientific basic an practical applications third edition. Cambridge University Press.

Steiner, N. J., Sheldrick, R. ., Gotthelf, D., \& Perrin, E. C. (2011). Computer-based attention training in the schools for children with Attention Deficit/Hyperactivity Disorder: A preliminary trial. Clinical Pediatrics, 50(7), 615-622. https:// doi.org/10.1177/0009922810397887

Tucha, O., Tucha, L., Kaumann, G., König, S., Lange, K. M., Stasik, D., Streather, Z., Engelschalk, T., \& Lange, K. W. (2011). Training of attention functions in children with attention deficit hyperactivity disorder. Attention Deficit and Hyperactivity Disorders, 3(3), 271-283. https://doi.org/10.1007/s12402-0110059-x

Wickens, C. D., Sallie, G, B., \& Yili, L. (2004). An introduction to human factors engineering (2nd ed.). Pearson.

Wiratika, K. D. (2016). Penambahan tampilan skor dalam Pelatihan Peningkatan Kemampuan Mempertahankan Perhatian (PKMP) untuk meningkatkan sustained attention pada anak dengan Gangguan Pemusatan Perhatian. UNPAD. 
Received 23 July 2020

Revised 2 December 2020

Accepted 5 January 2021 